\title{
Oxytocin Attenuates Stress-Induced c-fos mRNA Expression in Specific Forebrain Regions Associated with Modulation of Hypothalamo-Pituitary-Adrenal Activity
}

\author{
Richard J. Windle, ${ }^{2 \star}$ Yvonne M. Kershaw, ${ }^{1 \star}$ Nola Shanks, ${ }^{1}$ Susan A. Wood, ${ }^{1}$ Stafford L. Lightman, ${ }^{1}$ and \\ Colin D. Ingram ${ }^{1,3}$ \\ ${ }^{1}$ University Research Centre for Neuroendocrinology, University of Bristol, Bristol Royal Infirmary, Bristol BS2 8HW, United Kingdom, ${ }^{2}$ University of \\ Nottingham, Human and Clinical Sciences Research Centre, Queen's Medical Centre, Nottingham NG7 2UH, United Kingdom, and ${ }^{3}$ School of Neurology, \\ Neurobiology, and Psychiatry, University of Newcastle, Royal Victoria Infirmary, Newcastle upon Tyne NE1 4LP, United Kingdom
}

We reported previously that the neuropeptide oxytocin attenuates stress-induced hypothalamo-pituitary-adrenal (HPA) activity and anxiety behavior. This study sought to identify forebrain target sites through which oxytocin may mediate its anti-stress effects. Ovariectomized, estradiol-treated rats received intracerebroventricular infusions of oxytocin ( $1 \mathrm{or} 10 \mathrm{ng} / \mathrm{hr}$ ) or vasopressin (10 ng/hr), and the patterns of neuronal activation after restraint stress were determined by semiquantitative mapping of c-fos mRNA expression. Oxytocin administration significantly attenuated the release of ACTH and corticosterone and the increase in corticotropin-releasing factor mRNA expression in the hypothalamic paraventricular nucleus (PVN) in response to 30 min restraint. Restraint also induced the expression of c-fos mRNA in selective regions of the forebrain, including the PVN, paraventricular thalamic nucleus, habenula, medial amygdala, ventrolateral septum (LSV), most subfields of the dorsal and ventral hippocampus, and piriform and endopiriform cortices. In most cases, this level of gene expression was unaffected by concomitant administration of oxytocin. However, in the PVN, LSV, and throughout all subfields of the dorsal hippocampus, restraint evoked no detectable increase in c-fos mRNA in animals treated with either dose of oxytocin. Vasopressin had no effects on either HPA axis responses or neuronal activation in response to restraint, indicating that the effects were highly peptide selective. These data show that central oxytocin attenuates both the stress-induced neuroendocrine and molecular responses of the HPA axis and that the dorsal hippocampus, LSV, and PVN constitute an oxytocin-sensitive forebrain stress circuit.

Key words: oxytocin; HPA axis; ventrolateral septum; ACTH; vasopressin; paraventricular nucleus; corticosterone; amygdala; hippocampus; restraint stress; c-fos; immediate-early gene; limbic; thalamus; septum; corticotrophin-releasing factor

\section{Introduction}

Recent studies have shown that the neuropeptide oxytocin possesses potent anxiolytic properties (McCarthy et al., 1996; Windle et al., 1997a; Bale et al., 2001; Neumann, 2002) and suppresses stress-induced hypothalamo-pituitary-adrenal (HPA) activity (Windle et al., 1997a). Furthermore, the potentiation of stressinduced HPA activity and of anxiety behavior on the elevated plus maze by central administration of an oxytocin antagonist indicates that endogenous oxytocin participates in this activity (Neumann et al., 2000a,b,c). In the rat, the release of oxytocin into the peripheral circulation in response to physical and psychological stressors has long been established (Lang et al., 1983;

\footnotetext{
Received July 22, 2003; revised Dec. 22, 2003; accepted Dec. 23, 2003.

We are grateful to the Wellcome Trust for financial support and P. Perks for technical support during these studies.

*R.J.W. and Y.M.K. contributed equally to this study.

Correspondence should be addressed to Dr. Richard Windle, University of Nottingham, Human and Clinical Sciences Research Centre, School of Nursing, Queen's Medical Centre, Nottingham NG7 2UH, UK. E-mail: richard.windle@nottingham.ac.uk.

DOI:10.1523/JNEUROSCI.3432-03.2004

Copyright $\odot 2004$ Society for Neuroscience $\quad 0270-6474 / 04 / 242974-09 \$ 15.00 / 0$
}

Gibbs, 1984). More recently, it has been shown that emotional stressors also evoke oxytocin release in various forebrain areas, including the hypothalamus and lateral septum (Nishioka et al., 1998; Wotjak et al., 1998; Engelmann et al., 1999, 2000; Ebner et al., 2000) in a way that is partially independent of its peripheral release as a hormone (Engelmann et al., 1999).

Oxytocinergic pathways are widely distributed throughout the CNS, and oxytocin receptors are present in many forebrain areas, including regions of hippocampus and amygdala, bed nuclei of the stria terminalis (BNST), ventrolateral septum (LSV), and several hypothalamic nuclei (Freund-Mercier et al., 1987; Tribollet et al., 1988; Condés-Lara et al., 1994; Barberis and Tribollet, 1996). Although a number of these areas participate in regulating both anxiety behavior and HPA activity, it is not known whether their activation by stress is modulated by oxytocin.

Many studies have explored the central pathways mediating the stress response by mapping neuronal activation using the proto-oncogene c-fos (Arnold et al., 1992; Smith et al., 1992; Chan et al., 1993; Chen and Herbert, 1995; Cullinan et al., 1995). Although widespread regions of the brain are activated by stress, 
when differential patterns of neuronal activation are studied, in terms of the nature of the stress (Emmert and Herman, 1999; Dayas et al., 2001), the intensity of the stimulus (Campeau and Watson, 1997), or the physiological state of the animal (da Costa et al., 1996), certain forebrain regions are consistently implicated in gating the stress-induced inputs to the paraventricular nucleus (PVN). Significantly, many of these areas, including the LSV, BNST, and medial and central amygdala, are also areas of the brain known to possess oxytocin receptors (Krémarik et al., 1992; Condés-Lara et al., 1994), making them potential target sites for the anti-stress and anxiolytic effects of the peptide. Thus, to define a potential oxytocin-sensitive stress circuit in the forebrain, we examined the effect of oxytocin on HPA activity and regional restraint-induced expression of c-fos mRNA.

\section{Materials and Methods}

Animals. All experiments used female Sprague Dawley rats (225-250 gm; Bantin-Kingman, Hull, UK) maintained under standard animal housing conditions, including a 14/10 hr light/dark illumination cycle (lights on at 5:00 A.M.). Because ovarian steroid variations occurring over the estrous cycle could influence oxytocin and oxytocin receptor expression (de Kloet et al., 1985; Patchev et al., 1993; Krémarik et al., 1995), each rat underwent bilateral ovariectomy and simultaneous implantation of a SILASTIC capsule ( $1.6 \mathrm{~mm}$ inner diameter; $10 \mathrm{~mm}$ length/100 gm body weight) containing $150 \mu \mathrm{g}$ of $17 \beta$ estradiol benzoate per milliliter of vegetable oil. This is known to produce estradiol concentrations within the normal diestrus range (Goodman, 1978). All surgical procedures were performed under a combination of Hypnorm $(0.32 \mathrm{mg} / \mathrm{kg}$ fentanyl citrate and $10 \mathrm{mg} / \mathrm{kg}$ fluanisone, i.m.; Janssen Pharmaceuticals, Oxford, UK) and diazepam (2.6 mg/kg i.p.; Phoenix Pharmaceuticals, Gloucester, UK) anesthesia. All procedures conformed to United Kingdom animal welfare legislation.

Central peptide administration. Osmotic minipumps (model 1007D; Durect, Cupertino, CA) were used to deliver oxytocin or vasopressin (Bachem, Saffron Waldon, UK). This method of administration obviated the needed for additional animal handling during the treatment period. Pumps, rated to deliver $0.52 \mu \mathrm{l} / \mathrm{hr}$ over a $7 \mathrm{~d}$ period, were filled with the appropriate peptide and were set to deliver saline only, 1 or $10 \mathrm{ng} / \mathrm{hr}$ oxytocin, or $10 \mathrm{ng} / \mathrm{hr}$ vasopressin. These doses of oxytocin have been shown to significantly attenuate stress-induced HPA activity (Windle et al., 1997a). Each pump was connected to a brain infusion device (Durect) and allowed to equilibrate overnight in isotonic saline. On the day after ovariectomy, each animal was reanesthetized, an area of the parietal bone was trephined, and the intracerebroventricular cannula was stereotaxically positioned in the lateral ventricle. The minipump was positioned subcutaneously between the scapulae, and the brain infusion device was secured to the skull using self-curing dental acrylic and stainless steel screws. After recovery, all animals were housed individually.

Experimental procedures. All studies were performed $5 \mathrm{~d}$ after surgical implantation of the osmotic minipumps. Animals that had been assigned to the restraint groups were removed from their home cage between 8:00 A.M. and 9:00 A.M. and placed in a cylindrical Perspex restrainer (diameter of $55 \mathrm{~mm}$ ). After $30 \mathrm{~min}$, animals were killed by decapitation. Trunk blood was collected into tubes containing $10 \mu \mathrm{l}$ of saturated EDTA and centrifuged, and the plasma was collected for subsequent hormone analysis. Brains were removed rapidly and frozen on dry ice for analysis of c-fos mRNA expression. To determine the effects of restraint on CRF mRNA expression, parallel groups of animals were restrained as above, but, after the $30 \mathrm{~min}$ period of restraint, they were returned to their home cage for an additional $210 \mathrm{~min}$. Thereafter, brains were collected as above. Blood and tissues were collected from nonrestrained animals at comparable times for both studies.

Tissue preparation and in situ hybridization. All brains were stored at $-80^{\circ} \mathrm{C}$ before analysis. Cryostat sections $(12 \mu \mathrm{m})$ were cut from forebrain regions shown to exhibit increased c-fos mRNA expression after restraint (Cullinan et al., 1995; da Costa et al., 1996; Dayas et al., 2001). Collection of sections onto gelatin-coated slides commenced rostral to the anterior nuclei of the BNST (bregma $+0.2 \mathrm{~mm}$; Paxinos and Watson, 1998) and continued to a level that was caudal to the central amygdala and dorsal hippocampus (bregma $-3.3 \mathrm{~mm}$ ). A block of tissue $\sim 1 \mathrm{~mm}$ thick was then discarded before a final series of sections were collected through the region of the ventral hippocampus (starting at bregma -4.8 $\mathrm{mm}$ ). A collection regimen was adopted that resulted in each slide containing four sections, each separated by $\sim 50 \mu \mathrm{m}$ through the region of interest. Thus, each slide contained a representative cross-section from a $200-\mu \mathrm{m}$-thick block through the region to be studied. All sections were stored at $-80^{\circ} \mathrm{C}$ until analysis. Sections through the PVN were collected in the same manner for analysis of CRF mRNA.

In situ hybridization for c-fos mRNA was performed as follows. Sense and antisense rat c-fos transcripts incorporating $\left[{ }^{35} \mathrm{~S}\right] \mathrm{UTP}$ were generated from the vector pGEM-3Z by inserting a $680 \mathrm{bp}$ fragment of rat c-fos. The probes were transcribed using an Sp6/T7 transcription kit according to the instructions of the manufacturer (Roche Products, Lewes, UK). Tissue sections were fixed in $4 \%$ paraformaldehyde and hybridized overnight at $50^{\circ} \mathrm{C}$ in hybridization buffer containing $50 \%$ formamide, $4 \times$ SSC, $1 \times$ Denhardt's solution $(0.02 \%$ Ficoll, $0.02 \%$ polyvinylpyrrolidone, and $0.02 \%$ BSA), and $10 \%$ dextran sulfate (molecular weight of 500,000), at $10^{6} \mathrm{cpm} /$ slide. Before adding riboprobe to the hybridization buffer, it was mixed with $2 \mu$ l of nucleic acid solution per slide $(500 \mu \mathrm{g} / \mathrm{ml}$ sheared, single-stranded salmon testis DNA and $250 \mu \mathrm{g} / \mathrm{ml}$ yeast tRNA), heated to $65^{\circ} \mathrm{C}$ for $5 \mathrm{~min}$, and quenched on ice. After hybridization, coverslips were gently lifted off in $1 \times$ SSC at room temperature, and the slides were washed for $15 \mathrm{~min}$ in two changes of $1 \times$ SSC and $50 \%$ formamide at $50^{\circ} \mathrm{C}$. Sections were then rinsed briefly in $1 \times \mathrm{SSC}$ at $37^{\circ} \mathrm{C}$ and incubated in $1 \times$ SSC containing $20 \mu \mathrm{g} / \mathrm{ml}$ RNase A for $30 \mathrm{~min}$ at $37^{\circ} \mathrm{C}$. Sections were again rinsed in $1 \times$ SSC and then washed three times for $15 \mathrm{~min}$ each in $1 \times$ SSC and $50 \%$ formamide at $50^{\circ} \mathrm{C}$, followed by two room temperature washes in $1 \times$ SSC for $5 \mathrm{~min}$ each. Slides were briefly dipped in water and then air dried.

For CRF mRNA analysis, hybridization was performed as described previously (Harbuz and Lightman, 1989). A synthetic 48-mer oligonucleotide probe complimentary to part of the exonic portion of the CRF mRNA coding sequence was used. This probe was end labeled with ${ }^{35} \mathrm{~S}$ using terminal deoxynucleotidyl transferase (Roche Products) to a specific activity of $5 \times 10^{17} \mathrm{dpm} / \mathrm{mol}$. Tissues fixed and dehydrated, as described above, were incubated overnight at $37^{\circ} \mathrm{C}$ with the probe diluted in hybridization buffer to $10^{5} \mathrm{cpm} /$ slide. After hybridization sections were washed with four $15 \mathrm{~min}$ changes of SSC at $50^{\circ} \mathrm{C}$, followed by two 30 min changes of SSC at room temperature. After a brief rinse in water, sections were air dried.

Sections for a given region of the brain and probe were hybridized in the same hybridization reaction and exposed to photographic film (Hyperfilm; Amersham Biosciences, Bucks, UK) together with a series of ${ }^{35} \mathrm{~S}$ standards. After an exposure time of $14 \mathrm{~d}$ for the CRF mRNA probe and 6-21 d for the c-fos mRNA probe, the exposed films were developed. After hybridization, each slide was stained with cresyl violet to confirm the presence of the structures of interest, and any case in which the structure was absent or could not be accurately quantified was excluded from additional analysis. Numbers of replicates in each treatment group are indicated in the figure legends. All analysis and any exclusions were conducted blind to the treatment groups. The developed photographic films were subject to densitometric analysis using the public access Image software (http://rsb.info.nih.gov/ij/). The integrated optical density (area detected above threshold $\times$ mean optical density within the thresholded area) was measured for each of the structures expressing c-fos message in the sections, with the mean value for a given animal being determined from all sections containing that structure. Peptide treatments and stress procedures were unknown to those performing the in situ analysis.

Hormone analysis. Total plasma corticosterone concentrations were measured directly in plasma by radioimmunoassay using a citrate buffer at $\mathrm{pH} 3.0$ to denature the binding globulin ( $1 \mu \mathrm{l}$ of plasma fraction diluted in $100 \mu$ l of buffer), antiserum kindly supplied by Professor G. Makara (Institute of Experimental Medicine, Budapest, Hungary), and $\left[{ }^{125} \mathrm{I}\right]$ corticosterone (ICN Biomedicals, Irvine, CA) with a specific activity of $2-3 \mathrm{mCi} / \mu \mathrm{g}$. ACTH levels were determined using a commercially 


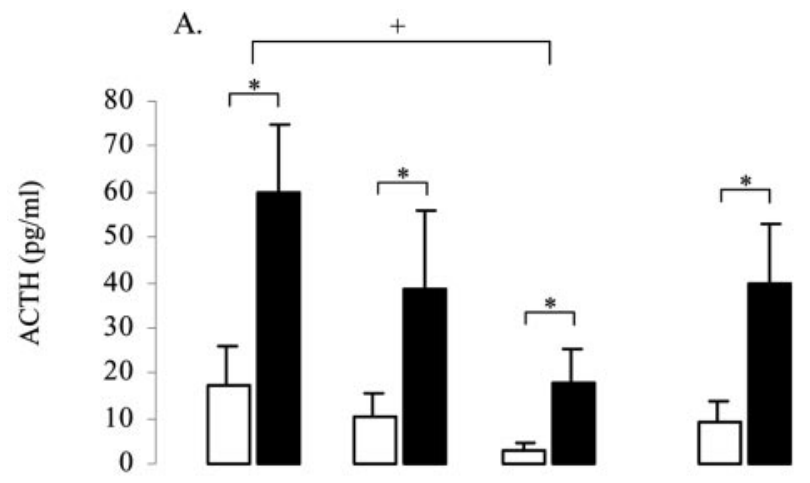

B.

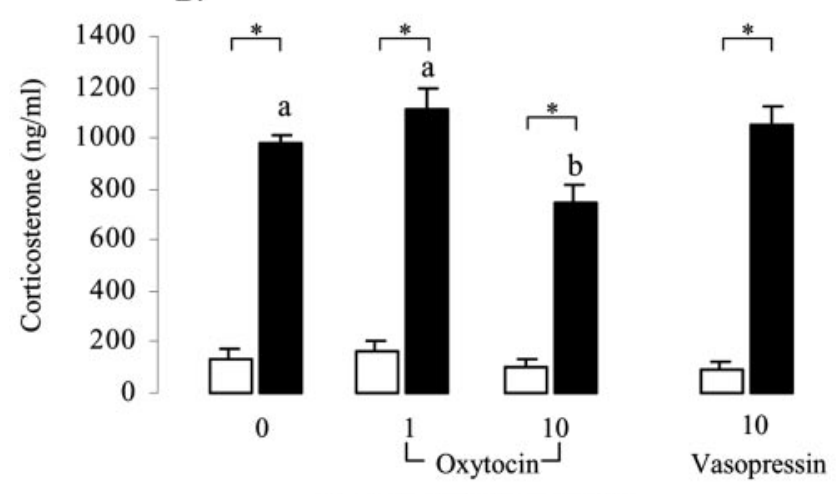

Peptide administered (n/gh)

Figure 1. The effect of central oxytocin and vasopressin administration on plasma ACTH $(A)$ and corticosterone $(B)$ concentrations in control animals (open bars) or after a $30 \mathrm{~min}$ period of restraint (filled bars). Groups of ovariectomized, estradiol-treated rats were infused centrally with either saline or saline containing 1 or $10 \mathrm{ng} / \mathrm{hr}$ oxytocin or $10 \mathrm{ng} / \mathrm{hr}$ vasopressin for a period of $5 \mathrm{~d}$ before restraint. Values represent the mean $\pm \mathrm{SE} ; n=8-12 .{ }^{*} p<0.05$, one-tailed $t$ test versus nonrestrained controls infused with the same treatment; ${ }^{+} p<0.05$, post hoc Tukey's test in ANOVA; $a, b$, bars labeled with different letters differ significantly by post hoc Tukey's test in which a significant interaction was detected in the ANOVA.

available immunoradiometric assay kit (Nicholls Institute Diagnostics, Capistrano, CA)

Statistical analysis. Values represent either individual data sets or the mean \pm SE for groups. Absolute measurements for hormone concentrations are given, but gene expression data are expressed in arbitrary optical density units. Primary analysis involved a two-way ANOVA to determine significant effects of restraint and/or peptide treatment on the hormone and gene expression data performed separately for groups treated with saline and different doses of oxytocin or with saline and vasopressin. When a significant interaction was detected, post hoc Tukey's tests were applied. All restrained groups were compared with their appropriate control by one-tailed $t$ test on the basis of our a priori hypothesis that restraint increases levels of hormones and c-fos mRNA expression. Values of $p<0.05$ are reported as significant.

\section{Results}

\section{Effect of oxytocin on restraint-induced HPA activity}

In all treatment groups, restraint stress evoked significant increases in both ACTH (Fig. 1A) and corticosterone concentrations (Fig. $1 B$ ). Intracerebroventricular administration of oxytocin significantly attenuated these responses. Oxytocin caused a dose-dependent suppression of both basal and stimulated concentrations of ACTH (main effect of restraint, $F_{(1,64)}=9.3, p=$ 0.003; main effect of dose, $F_{(2,64)}=3.2, p<0.05$ ) (Fig. $1 A$ ), and post hoc tests revealed that the effect of peptide reached significance with the $10 \mathrm{ng} / \mathrm{hr}$ dose. ANOVA indicated no interaction between treatment and restraint. In contrast, vasopressin had no
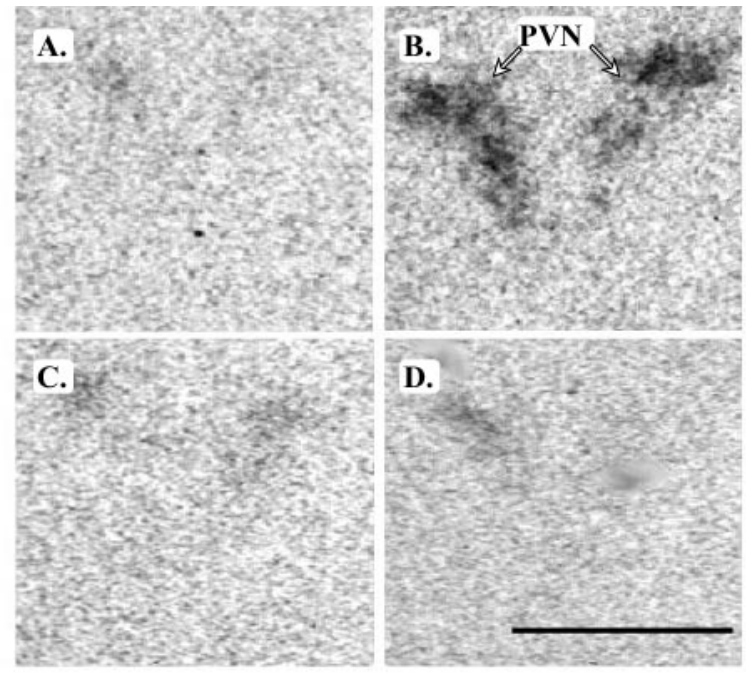

E.
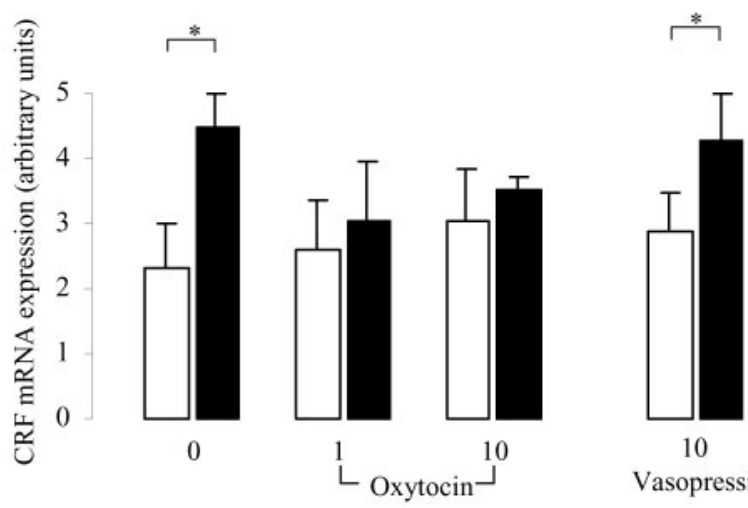

10

Vasopressin

Peptide administered (n/gh)

Figure 2. The effect of central infusion of oxytocin and vasopressin on restraint-induced CRF mRNA expression in the PVN. $A-D$, Images of autoradiograms demonstrating the distribution of hybridized CRF mRNA in the PVN of nonrestrained $(A, C)$ and restrained $(B, D)$ ovariectomized, estradiol-treated rats infused centrally with either saline $(A, B)$ or $10 \mathrm{ng} / \mathrm{hr}$ oxytocin $(C, D)$. Scale bar, $100 \mu \mathrm{m}$. Note that the marked expression of CRF mRNA induced by restraint in the salineinfused animal $(B)$ is absent in the oxytocin-infused animal ( $D)$. E, CRF mRNA expression levels in control animals (open bars) or after a 30 min period of restraint (filled bars). Values shown are the mean \pm SE of integrated optical density measurements in arbitrary units $(n=4-6) .{ }^{*} p<$ 0.05 , one-tailed $t$ test versus nonrestrained controls infused with the same treatment.

significant effect on basal or restraint-induced ACTH release. Within the oxytocin-treated groups, corticosterone levels were also significantly affected by restraint $\left(F_{(1,64)}=340, p<0.001\right)$ (Fig. $1 B)$, and there was a significant effect of peptide $\left(F_{(2,64)}=\right.$ $7.9, p<0.001)$ and a significant interaction $\left(F_{(2,64)}=4.1, p=\right.$ 0.02). Post hoc tests revealed that restraint-induced levels of corticosterone were significantly lower in the group receiving 10 $\mathrm{ng} / \mathrm{hr}$ oxytocin compared with either of the other two groups (Fig. $1 B$ ). Again, vasopressin did not have any effect on corticosterone levels. In addition to the endocrine response, restraint also significantly increased CRF mRNA expression within the PVN of saline-treated animals $(p<0.05)$ (Fig. $2 B, E)$ and animals infused with vasopressin $(p<0.05)$ (Fig. $2 E)$. ANOVA of data from animals treated with saline and vasopressin showed a highly significant main effect of restraint $\left(F_{(1,17)}=10.7, p=\right.$ 0.004 ) but no effect of peptide. This effect of restraint was lost in the analysis of groups treated with oxytocin $\left(F_{(1,24)}=3.0, p=\right.$ 0.095 ) attributable to a small increase in basal expression and the 
Table 1. $p$ values from the statistical analysis of the effects of restraint on c-fos mRNA expression in areas of the forebrain and modulation of this expression by concomitant central infusion of oxytocin or vasopressin

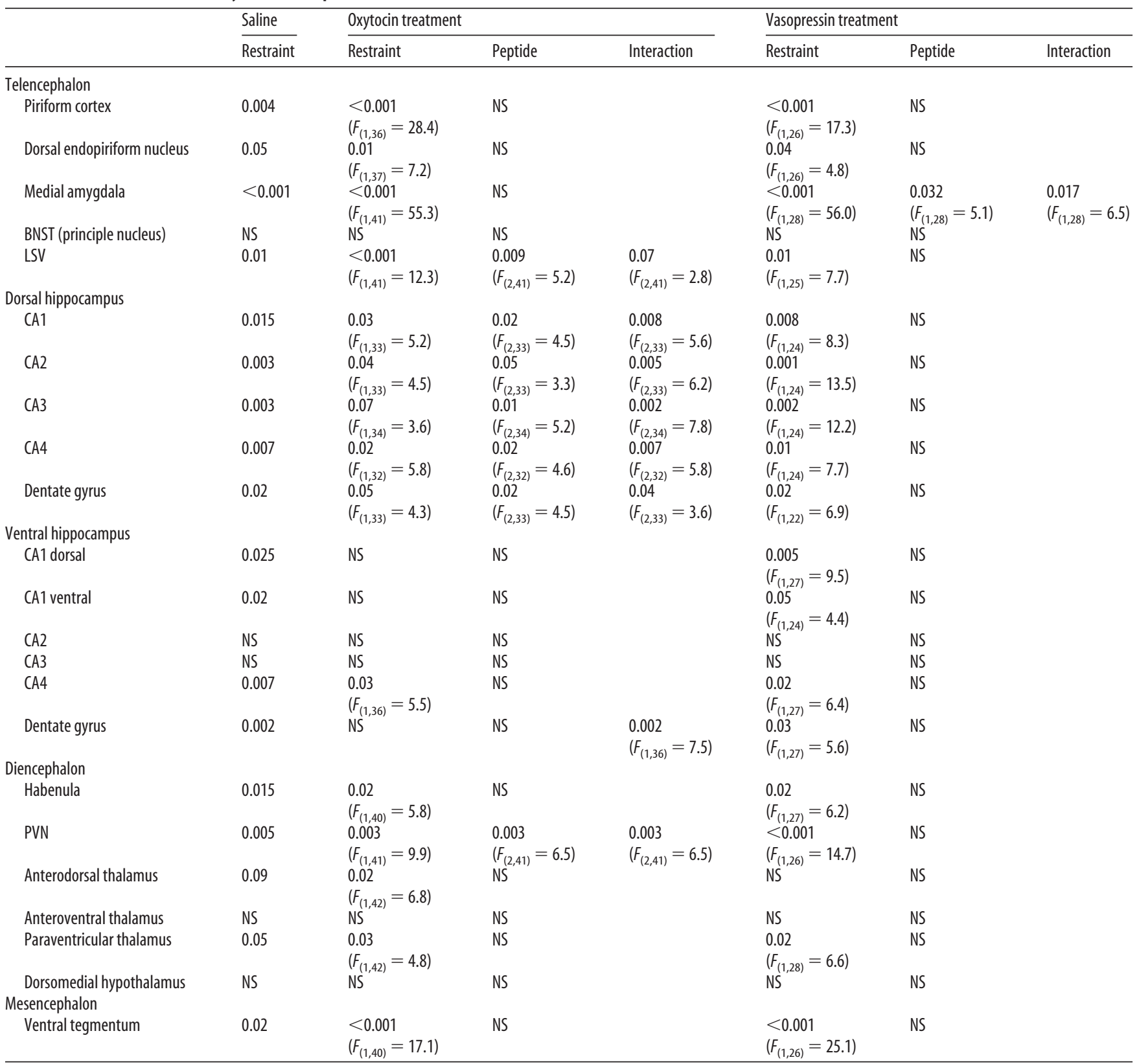

The first column shows the level of significance of the restraint-induced increase in c-fos mRNA expression in saline-infused controls (Student's $t$ tests). Subsequent columns show the modulation of the c-fos response to restraint by either oxytocin or vasopressin (values shown are derived from separate two-way ANOVA). NS, $p>0.05$.

lack of any increase in CRF mRNA in animals infused with oxytocin at either 1 or $10 \mathrm{ng} / \mathrm{hr}$ (Fig. 2E).

\section{Regional expression of c-fos mRNA in the forebrain}

A low level of basal c-fos mRNA expression was detected in a number distinct forebrain nuclei encompassed within the sections analyzed (areas listed in Table 1). Restraint stress caused a significant increase in the level of expression in the majority of these areas but had no significant effect in the principle nucleus of the BNST, CA2 and CA3 subfields of the ventral hippocampus, anteroventral thalamic nucleus, or dorsomedial hypothalamic area (Table 1). It is notable that no c-fos mRNA expression (either basal or stress-induced) was detected in other stress-related areas encompassed by the forebrain sections, including the oval nucleus of the BNST, the central nucleus of the amygdala, and the cingulate gyrus.

Oxytocin had a highly regional effect on this restraint-induced c-fos mRNA expression with two distinct patterns of peptide sensitivity, as follows.

Oxytocin-sensitive regions

In the PVN, restraint stress caused a marked increase in c-fos mRNA expression throughout the nucleus (Fig. $3 B$ ), consistent with the neuroendocrine response. This restraint-induced response was unaffected by infusion of vasopressin (main effect of restraint, $F_{(1,26)}=14.7, p<0.001$; effect of peptide, NS). However, infusion with different doses of oxytocin had both a significant peptide effect $\left(F_{(2,41)}=6.5, p=0.003\right)$ and a significant 

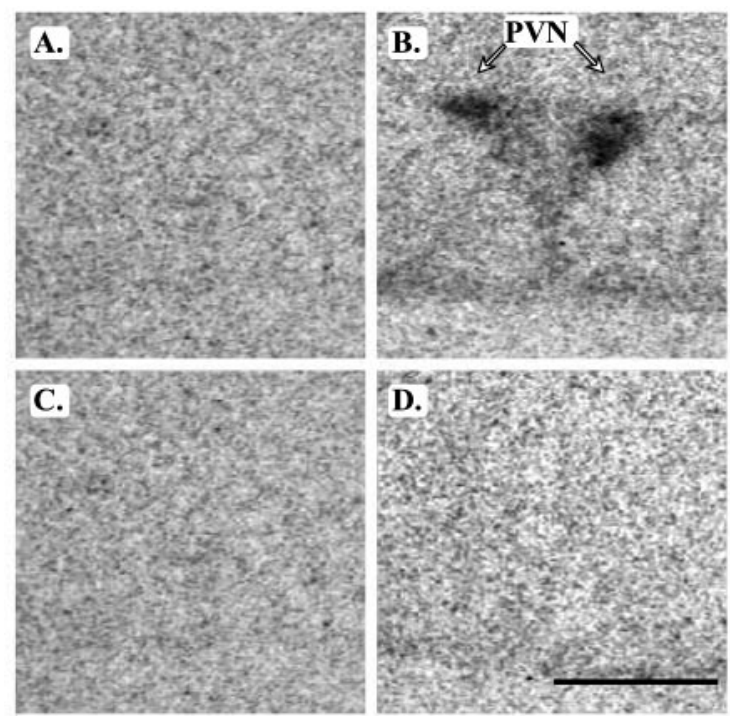

E.

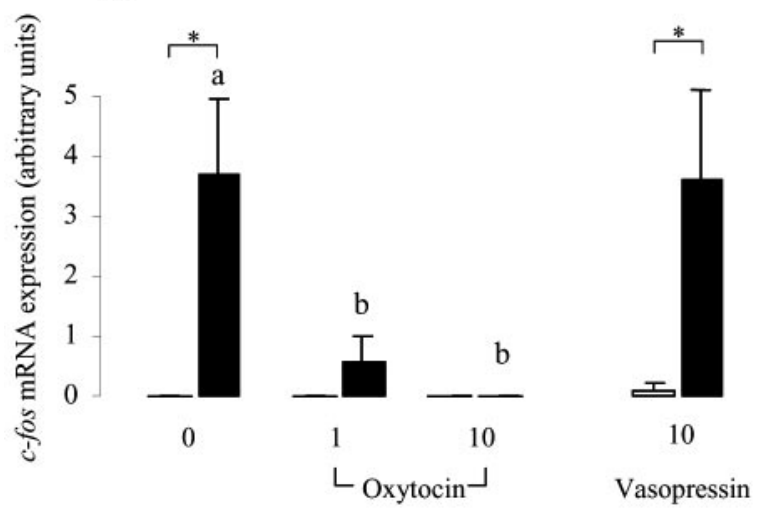

Peptide administered ( $\mathrm{n} / \mathrm{gh})$

Figure 3. Effect of central infusion of oxytocin and vasopressin on restraint-induced c-fos mRNA expression in the PVN. $A-D$, Images of representative autoradiograms showing the hybridized c-fos mRNA signal in the PVN of nonrestrained $(A, C$ and restrained $(B, D)$ ovariectomized, estradiol-treated rats infused centrally with either saline $(A, B)$ or $10 \mathrm{ng} / \mathrm{hr}$ oxytocin $(C$, $D)$. The restraint-induced signal in the saline-infused animal $(B)$ is absent in the oxytocininfused animal $(D)$. Scale bar, $100 \mu \mathrm{m}$. Note that, in all cases, the presence of the PVN was confirmed in adjacent sections. $E$, Values for mean $\pm \operatorname{SE}(n=6-8)$ integrated optical density measurements of c-fos mRNA expression in the PVN of control animals (open bars) and animals after a 30 min restraint (filled bars). ${ }^{*} p<0.05$, one-tailed $t$ test versus nonrestrained controls infused with the same treatment; $a, b$, bars labeled with different letters differ significantly by post hoc Tukey's test in which a significant interaction was detected in the ANOVA.

interaction $\left(F_{(2,41)}=6.5, p=0.003\right)$. Post hoc tests showed that restraint-induced levels of c-fos mRNA were significantly reduced by both doses of oxytocin, with no detectable expression in the presence of the highest rate of administration (Fig. $3 D, E$ ). c-fos mRNA expression throughout the dorsal hippocampal formation (Fig. 4) and selective regions of the ventral hippocampal formation (Table 1) was also increased by restraint stress in the saline-treated animals, with the effect focused on the pyramidal cell layer. Within the dorsal hippocampus, the response in the hippocampal subfields (CA1-CA4) and dentate gyrus to restraint stress were all significantly reduced by concomitant administration of both doses of oxytocin (Fig. $4 E-G$, Table 1), although no effect was seen on basal c-fos mRNA expression. In contrast to the dorsal hippocampus, oxytocin had no effect on c-fos mRNA expression in the ventral hippocampus (Table 1). Vasopressin had
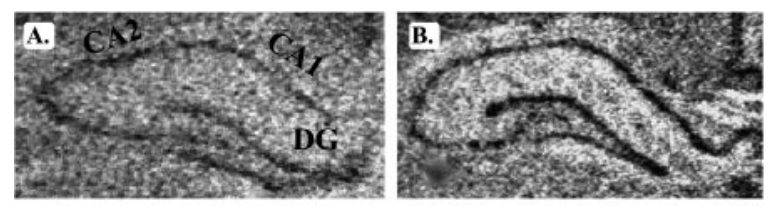

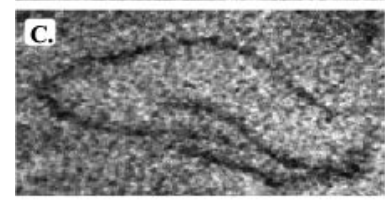

E. $*$

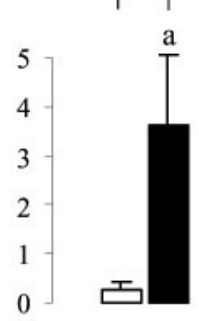

F.

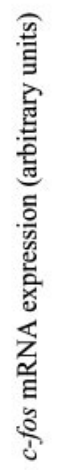<smiles>C1CCCCC1</smiles>

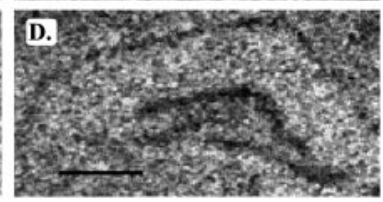

CA1
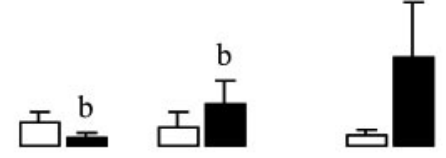

$\mathrm{CA} 2$

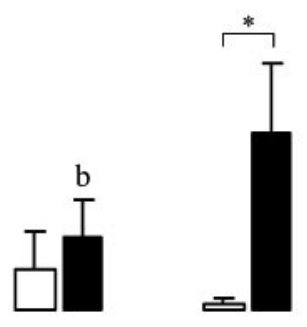

Dentate Gyrus

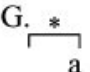

$\left.\begin{array}{l}5 \\ 4 \\ 3 \\ 2 \\ 1 \\ 0\end{array}\right]$ 工

0

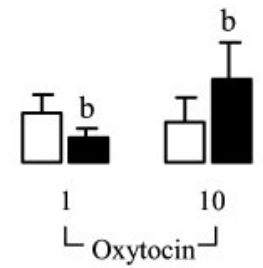

Peptide administered (n/gh)

Figure 4. Effect of oxytocin and vasopressin on restraint-induced c-fos mRNA expression in dorsal hippocampus. $A-D$, Images of representative autoradiograms showing the distribution of hybridized $c$-fos mRNA in the dorsal hippocampus of nonrestrained $(A, C)$ and restrained $(B, D)$ ovariectomized, estradiol-treated rats infused centrally with saline $(A, B)$ or $10 \mathrm{ng} / \mathrm{hr}$ oxytocin $(C, D)$. The subfields indicated are CA1, CA2, and dentate gyrus (DG). Scale bar, $100 \mu \mathrm{m}$. c-fos mRNA expression is lower in restrained animals treated with oxytocin $(D)$ than those infused with saline $(B) . E, F$, Values of mean $\pm S E(n=5-8)$ integrated optical density measurements of $c$-fos mRNA expression in the CA1 (E), CA2 ( $F$ ), and dentate gyrus ( $G)$ of control animals (open bars) and animals after a 30 min restraint (filled bars). ${ }^{*} p<0.05$, one-tailed $t$ test versus nonrestrained controls infused with the same treatment; $a, b$, bars labeled with different letters differ significantly by post hoc Tukey's test in which a significant interaction was detected in the ANOVA.

no effect on restraint-induced c-fos mRNA expression in any of the hippocampal areas. Finally, within this group of stressactivated structures, a similar pattern of peptide effects was seen in the LSV. Restraint stress caused a significant increase in c-fos mRNA expression within this region in saline- and vasopressin- 

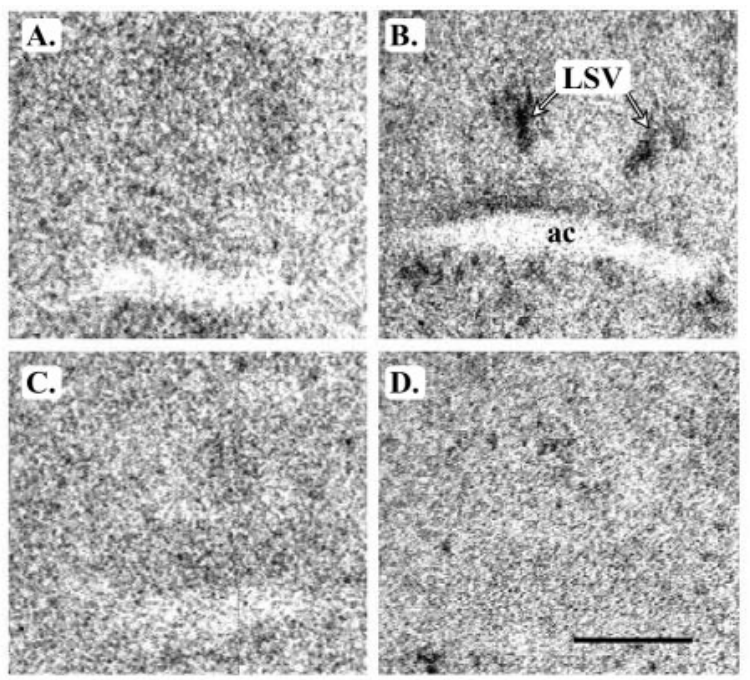

E.

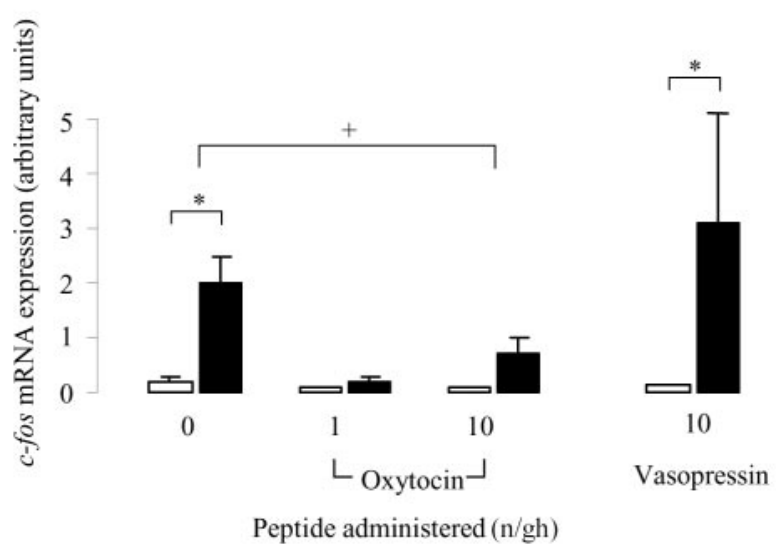

Figure 5. Effect of oxytocin and vasopressin on restraint-induced c-fos mRNA expression in the LSV. $A-D$, Images of representative autoradiograms showing the distribution of hybridized c-fos mRNA in the LSV of nonrestrained $(A, C)$ and restrained $(B, D)$ ovariectomized, estradioltreated rats infused centrally with saline $(A, B)$ or $10 \mathrm{ng} / \mathrm{hr}$ oxytocin $(C, D)$. Note the clear area of hybridized signal just above the anterior commissure (ac) of the saline-infused restrained animal. Scale bar, $100 \mu \mathrm{m}$. E, Mean \pm SE $(n=6-8)$ integrated optical density measurements of c-fos mRNA expression in the LSV of control animals (open bars) or animals undergoing a $30 \mathrm{~min}$ period of restraint (filled bars). ${ }^{*} p<0.05$, compared with nonrestrained controls infused with the same treatment. ${ }^{+} p<0.05$, post hoc Tukey's test in ANOVA.

infused animals $\left(F_{(1,27)}=8.9, p=0.006\right)$, but there was no effect of peptide (Fig. $5 B, E$ ). Animals treated with different doses of oxytocin not only showed a significant effect of restraint $\left(F_{(1,41)}=12.3, p<0.001\right)$ but also an effect of peptide dose $\left(F_{(2,41)}=5.2, p<0.009\right)$. Although there was no effect of restraint in either oxytocin-treated group (Fig. $5 D, E$ ), the interaction term was of borderline significance $\left(F_{(2,41)}=2.8, p=0.07\right)$.

\section{Oxytocin-insensitive regions}

The effect of oxytocin was highly region specific, and all other areas displaying restraint-induced increase in c-fos mRNA showed no significant effects of oxytocin (Table 1). For example, within the piriform cortex (Fig. 6A), both basal and restraintinduced c-fos mRNA expression were equal in all treatment groups. Vasopressin was without effect in all areas except the medial amygdala (Fig. 6B, Table 1 ) in which there was a significant main effect of peptide $\left(F_{(1,28)}=5.1, p=0.03\right)$ and a significant interaction $\left(F_{(1,28)}=6.5, p=0.02\right)$. Post hoc tests showed

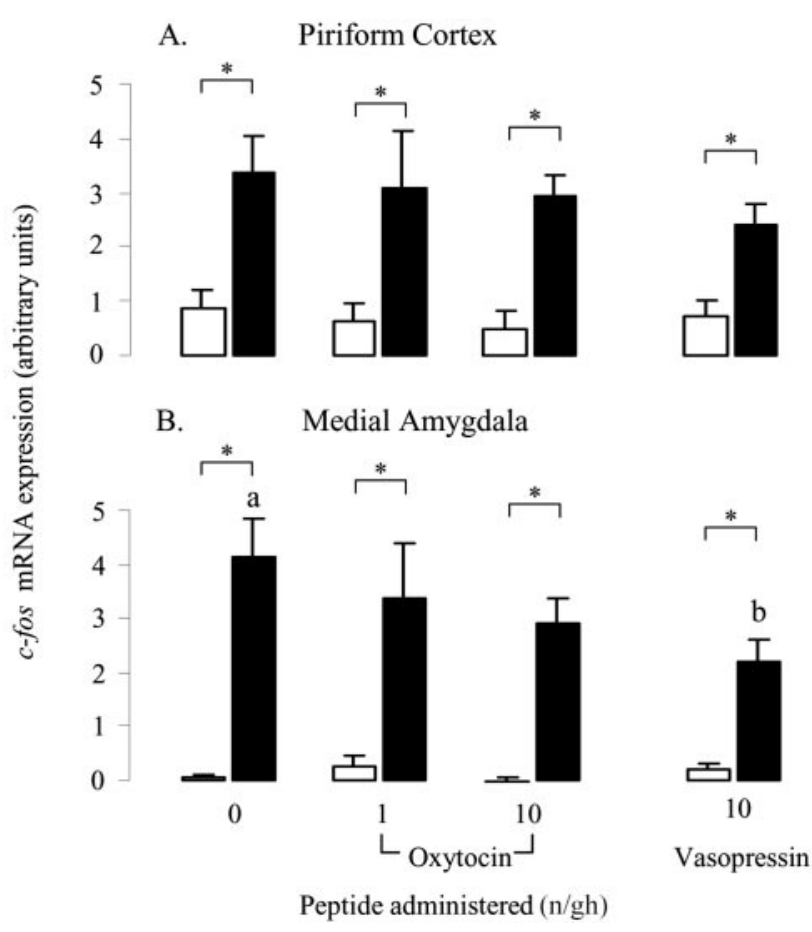

Figure 6. The effect of central oxytocin and vasopressin administration on c-fos mRNA expression within the piriform cortex $(A)$ and medial amygdala $(B)$ of control animals (open bars) or after a 30 min period of restraint (filled bars). Groups of ovariectomized, estradiol-treated rats were infused with saline or saline containing either oxytocin (1 or $10 \mathrm{ng} / \mathrm{hr}$ ) or vasopressin (10 $\mathrm{ng} / \mathrm{hr}$ ) for a period of $5 \mathrm{~d}$ before study. Values are the mean \pm SE of integrated optical density measurements $(n=6-8)$. ${ }^{*} p<0.05$, one-tailed $t$ test versus nonrestrained controls infused with the same treatment; $a, b$, bars labeled with different letters differ significantly by post hoc Tukey's test in which a significant interaction was detected in the ANOVA.

that this was attributable to a small reduction in restraintinduced expression (Fig. 6B).

\section{Discussion}

This study demonstrates that central administration of a low dose of oxytocin causes peptide-selective attenuation of HPA activation by the psychological stress of restraint and that this is associated with a highly region-specific suppression of stressactivated neural circuits, including the PVN, LSV, and dorsal hippocampus. This circuit may play a major role in stress reactivity, particularly during physiological states in which oxytocin levels are increased.

Similar to the response to a less severe noise stress (Windle et al., 1997a), the present data show that central infusion of oxytocin significantly suppresses the corticosterone response to restraint stress. Furthermore, we now show that there is a greater effect on stress-induced ACTH release and an absence of a detectable increase in CRF mRNA transcription that is normally evoked by restraint. This apparent graded effect on the HPA axis most likely arises from the fact that a small residual release of CRF, although insufficient to evoke a transcriptional response, is capable of causing pituitary corticotroph activation. The consequent increase in ACTH, although significantly reduced, is still sufficient to induce near-maximal adrenal corticosterone synthesis.

Before interpreting these data in terms of agonist activation of central oxytocin receptors, it is important to discount other potential modes of action. First, some reports suggest that central vasopressin may have a role in modulating HPA activity (Kalsbeek et al., 1993), but, in both the present study and our previous 
report on responses to noise stress (Windle et al., 1997a), vasopressin was without effect at doses up to $100 \mathrm{ng} / \mathrm{hr}$. This suggests that the functional effects are highly peptide selective, despite the fact that vasopressin has a high affinity for the rat brain oxytocin receptor (Audigier and Barberis, 1985). This functional selectivity is unlikely to arise from a degradation of vasopressin in the Alzet pump in vivo, because studies of the cardiovascular effects of vasopressin have shown that Alzet minipumps can sustain delivery of biologically active vasopressin over a $7 \mathrm{~d}$ period (Tsuchihashi et al., 1993). Second, although we cannot completely exclude a possible direct inhibition of the pituitary-adrenal axis attributable to oxytocin leakage from the ventricular system, this is unlikely because all evidence suggests that circulating oxytocin acts to stimulate rather than inhibit ACTH release at the pituitary (Antoni et al., 1983; Gibbs et al., 1984; Rivier and Shen, 1994). Furthermore, doses that have a peripheral action [e.g., 30 $\mu \mathrm{g} / \mathrm{kg}$, i.v. (Rivier and Shen 1994)] are much higher than those that have a central inhibitory effect. Interestingly, very large peripheral doses of oxytocin ( $1 \mathrm{mg} / \mathrm{kg}$, s.c.) have been reported to have a biphasic action on the HPA axis, acutely increasing corticosterone but subsequently causing suppression (Petersson et al., 1999), and this latter effect may be attributable to the low level of oxytocin that penetrates the ventricular system from the circulation (Mens et al., 1983). Strong support for a central site for oxytocin suppression of HPA activity also comes from the present observation of near-total suppression of the PVN response to stress, as measured by c-fos and CRF mRNA levels. Finally, it is worth noting that, although oxytocin can induce homologous desensitization of oxytocin receptors (Insel et al., 1992), this occurs with a dose 100 times higher than our lowest effective dose and is unlikely to contribute to the effects seen.

The suppressive effects of oxytocin on the HPA axis may be partly mediated within the PVN itself. Neurons within the PVN are sensitive to oxytocin (Inenaga and Yamashita, 1986), and oxytocin binding sites can be detected here, at least under certain conditions (Freund-Mercier et al., 1994). Furthermore, the release of oxytocin within the PVN during stress has been demonstrated clearly (Nishioka et al., 1998; Engelmann et al., 1999), although much of this probably represents dendritic release from the magnocellular neurons (Ludwig, 1998). More direct evidence for an action of oxytocin within the PVN has come from the observation that infusion of an oxytocin antagonist directly into the PVN downregulates the stress response (Neumann et al., 2000a,b,c). However, if oxytocin does have its primary action within the PVN, it is unlikely to be through a direct effect on the CRF-producing parvocellular neurons, because the majority of neuronal responses to oxytocin are excitatory (Inenaga and Yamashita, 1986). Thus, it is more likely that oxytocin acts through an inhibitory intermediary, such as the perinuclear GABAergic neurons that regulate inputs to the PVN (Herman et al., 2002) or neurons of the BNST-lateral septal region that act as a relay for limbic afferents (Cullinan et al., 1993).

In addition to the PVN, the present data demonstrate oxytocin-induced attenuation of responses in some, but not all, forebrain regions activated by restraint. The differentiation between those areas that continue to show similar activation despite the declining neuroendocrine response (e.g., piriform cortex and medial amygdala) and those that show parallel attenuation of responses (e.g., PVN and LSV) suggests that the former are either upstream of any oxytocin-sensitive gating mechanism or are not involved in mediating the HPA component of the stress response. In this respect, the piriform cortex showed a robust response to stress that was unaltered by oxytocin administration. Similar nondiscriminatory stress responses within this area have been seen after other psychological stresses (da Costa et al., 1996; Campeau and Watson, 1997) and probably relate to its role in stressrelated coping behavior rather a direct effect on HPA function.

Despite the presence of oxytocin receptors (Krémarik et al., 1992; Condés-Lara et al., 1994; Veinante and Freund-Mercier, 1997), the medial amygdala was also unaffected by oxytocin infusion and was the only area of the amygdala to show any activation after restraint. In this respect, we and others (Dayas et al., 2001) have observed that the psychological stress of restraint does not induce c-fos expression in the central amygdala, despite its importance in coordinating fear and anxiety responses (Davis and Shi, 1999). This pattern of amygdala activation confirms the discriminative nature of the subnuclei responses to psychological and physical stress stimuli (Chen and Herbert, 1995; Dayas et al., 2001). Similar stressor-specific activation probably occurs in the BNST (Emmert and Herman, 1999), an area of the brain through which amygdalar signals are relayed to the hypothalamus (Walker et al., 2003) and in which we did not detect any measurable effect of restraint.

The two areas that did show close correlation with the effect of oxytocin in the PVN were the LSV and dorsal hippocampus. The LSV is an important relay for stress-related afferent inputs to the PVN (Silverman et al., 1981), and activation of this area has been closely associated with HPA activity. For example, in studies using graded noise stress stimuli, Campeau and Watson (1997) demonstrated that, unlike many of the forebrain regions activated by this stress, the LSV showed a pattern of activity that closely reflected that seen within the HPA axis, suggesting that the two might share a common control mechanism. Not only is the LSV implicated as a gating relay for PVN control, but it possesses oxytocin binding sites (Insel, 1990; Krémarik et al., 1992; Patchev et al., 1993) and neurons sensitive to oxytocin (see distribution by Ingram et al., 1990). Furthermore, the release of oxytocin into the septal region has been suggested to mediate the behavioral responses to stress (Engelmann et al., 2000), possibly including its anxiolytic actions (Uvnäs-Moberg et al., 1994; Windle et al., 1997a). Thus, the present novel observation that oxytocin is able to block restraint-induced c-fos mRNA induction in the LSV indicates an important mechanism for the gating and integration of responses to stress.

The other major site of oxytocin action was the dorsal hippocampus. Widespread neuronal activation was detected throughout the hippocampal formation in response to restraint, similar to previous studies (Melia et al., 1994; Chowdhury et al., 2000). Oxytocin binding sites (Freund-Mercier et al., 1987) and oxytocin-sensitive neurons (Mühlethaler et al., 1983; Zaninetti and Raggenbass, 2000) are present in the hippocampus, and it is possible that they may exert an action through modulation of the well established glucocorticoid negative feedback pathway. Indeed, it has been shown that oxytocin receptors within the hippocampus are upregulated by stress, perhaps representing a negative feedback loop within the system (Liberzon and Young, 1997). Furthermore, the efferent connections from the hippocampus to PVN pass through the LSV, and, therefore, the effects seen in the present study might illustrate part of a coordinated inhibitory pathway.

The demonstration of oxytocin-mediated suppression of HPA activation and the associated neural circuitry has important implications for stress responses under different physiological conditions. For example, pregnancy and lactation are associated with an upregulation of central oxytocinergic pathways (Richard et al., 1991; Ingram et al., 1993) and a decrease in the HPA re- 
sponse to stress (Windle et al., 1997b; Neumann et al., 1998; Lightman et al., 2001). This appears to be an important adaptive mechanism that is also seen in humans (Altemus et al., 1995) and may well involve an action of oxytocin. Interestingly, during the peripartum period, there is an upregulation of oxytocin receptors within the LSV (Insel, 1990) and an increased neuronal sensitivity to oxytocin (Ingram and Wakerley, 1993; Wakerley et al., 1998). This change in oxytocin transmission coincides with a loss of stress-induced HPA reactivity and an attenuation of restraintinduced c-fos mRNA expression in the PVN and LSV, similar to that seen here with oxytocin administration (da Costa et al., 1996). Thus, a hippocampal-LSV-PVN circuit may play an important role in determining stress reactivity under this and other conditions of altered oxytocin neurotransmission.

\section{References}

Altemus M, Deuster PA, Galliven E, Carter CS, Gold PW (1995) Suppression of the hypothalamic pituitary-adrenal axis responses to stress in lactating women. J Clin Invest 80:2954-2959.

Antoni FA, Holmes MC, Jones MT (1983) Oxytocin as well as vasopressin potentiate ovine CRF in vitro. Peptides 4:411-415.

Arnold FJL, De Lucas Bueno M, Shier H, Hancock DC, Evan GI, Herbert J (1992) Expression of $c$-fos in regions of the basal limbic forebrain following intracerebroventricular corticotropin-releasing factor in unstressed or stressed male rats. Neuroscience 51:377-390.

Audigier S, Barberis C (1985) Pharmacological characterization of two specific binding sites for neurohypophyseal hormones in hippocampal synaptic plasma membranes of the rat. EMBO J 4:1407-1412.

Bale TL, David AM, Auger AP, Dorsa DM, McCarthy MM (2001) CNS region-specific oxytocin receptor expression: importance in regulation of anxiety and sex behavior. J Neurosci 21:2546-2552.

Barberis C, Tribollet E (1996) Vasopressin and oxytocin receptors in the central nervous system. Crit Rev Neurobiol 10:119-154.

Campeau S, Watson SJ (1997) Neuroendocrine and behavioral responses and brain pattern of $c$-fos induction associated with audiogenic stress. J Neuroendocrinol 9:577-588.

Chan RKW, Brown ER, Ericsson A, Kovacs KJ, Sawchenko PE (1993) A comparison of two immediate-early genes, c-fos and NGFI-B, as markers for functional activity in stress-related neuroendocrine circuitry. J Neurosci 13:5126-5138.

Chen X, Herbert J (1995) Regional changes in $c$-fos expression in the basal forebrain and brainstem during adaptation to repeated stress: correlations with cardiovascular, hypothermic and endocrine responses. Neuroscience 64:675-685.

Chowdhury GMI, Fujioka T, Nakamura S (2000) Induction and adaptation of Fos expression in the rat brain by two types of acute restraint stress. Brain Res Bull 52:171-182.

Condés-Lara M, Veinante P, Rabai M, Freund-Mercier M-J (1994) Correlation between oxytocin neuronal sensitivity and oxytocin-binding sites in the amygdala of the rat: electrophysiological and histological study. Brain Res 637:277-286.

Cullinan WE, Herman JP, Watson SJ (1993) Ventral subicular interaction with the hypothalamic paraventricular nucleus: evidence for a relay in the bed nucleus of the stria terminalis. J Comp Neurol 332:1-20.

Cullinan WE, Herman JP, Battaglia DF, Akil H, Watson SJ (1995) Pattern and time course of immediate early gene expression in the rat brain following acute stress. Neuroscience 64:477-505.

da Costa APC, Wood S, Ingram CD, Lightman SL (1996) Region-specific reduction in stress-induced $c$-fos mRNA expression during pregnancy and lactation. Brain Res 743:177-184.

Davis M, Shi C (1999) The extended amygdala: are the central nucleus of the amygdala and the bed nucleus of the stria terminalis differentially involved in fear versus anxiety? Ann NY Acad Sci 877:281-291.

Dayas CV, Buller KM, Crane JW, Xu Y, Day TA (2001) Stressor categorization: acute physical and psychological stressors elicit distinctive recruitment patterns in the amygdala and in medullary noradrenergic cell groups. Eur J Neurosci 14:1143-1152.

de Kloet ER, Voorhuis TAM, Elands J (1985) Oestradiol induced oxytocin binding sites in the rat hypothalamic ventromedial nucleus. Eur J Pharmacol 118:185-186.
Ebner K, Wotjak CT, Landgraf R, Engelmann M (2000) A single social defeat experience selectively stimulates the release of oxytocin, but not vasopressin, within septal brain areas of male rats. Brain Res 872:87-92.

Emmert MH, Herman JP (1999) Differential forebrain $c$-fos mRNA induction by ether inhalation and novelty: evidence for distinctive stress pathways. Brain Res 845:60-67.

Engelmann M, Ebner K, Landgraf R, Holsboer F, Wotjak CT (1999) Emotional stress triggers intrahypothalamic but not peripheral release of oxytocin in male rats. J Neuroendocrinol 11:867-872.

Engelmann, Wotjak CT, Ebner K, Landgraf R (2000) Behavioural impact of intraseptally released vasopressin and oxytocin in rats. Exp Physiol 85:125S-130S.

Freund-Mercier MJ, Stoeckel E, Palacios JM, Pazos A, Reichhart JM, Porte A, Richard Ph (1987) Pharmacological characteristics and anatomical distribution of $\left[{ }^{3} \mathrm{H}\right]$ oxytocin-binding sites in the Wistar rat brain studied by autoradiography. Neuroscience 20:599-614.

Freund-Mercier MJ, Stoeckel ME, Klein MJ (1994) Oxytocin receptors on oxytocin neurones: histoautoradiographic detection in the lactating rat. J Physiol (Lond) 480:155-161.

Gibbs DM (1984) Dissociation of oxytocin, vasopressin and corticotropin release during different types of stress. Life Sci 35:487-491.

Gibbs DM, Vale W, Rivier J, Yen SS (1984) Oxytocin potentiates the ACTHreleasing activity of CRF(41) but not vasopressin. Life Sci 34:2245-2249.

Goodman RL (1978) A quantitative analysis of the physiological role of estradiol and progesterone in the control of tonic and surge secretion of luteinizing hormone in the rat. Endocrinology 102:142-150.

Harbuz MS, Lightman SL (1989) Responses of hypothalamic and pituitary mRNA to physiological stress in the rat. J Endocrinol 122:705-711.

Herman JP, Tasker JG, Ziegler DR, Cullinan WE (2002) Local circuit regulation of paraventricular nucleus stress integration: glutamate-GABA connections. Pharmacol Biochem Behav 71:457-468.

Inenaga K, Yamashita H (1986) Excitation of neurones in the rat paraventricular nucleus in vitro by vasopressin and oxytocin. J Physiol (Lond) 370:165-180.

Ingram CD, Wakerley JB (1993) Post-partum increase in oxytocin-induced excitation of neurones in the bed nuclei of the stria terminalis in vitro. Brain Res 602:325-330.

Ingram CD, Cutler KL, Wakerley JB (1990) Oxytocin excites neurones in the bed nucleus of the stria terminalis of the lactating rat in vitro. Brain Res 527:167-170.

Insel TR (1990) Regional changes in brain oxytocin receptors post-partum: time course and relationship to maternal behaviour. J Neuroendocrinol 2:539-545.

Insel TR, Winslow JT, Witt DM (1992) Homologous regulation of brain oxytocin receptors. Endocrinology 130:2602-2608.

Kalsbeek A, Buijs RM, van Heerikhuize JJ, Arts M, van der Woude TP (1993) Vasopressin containing neurons of the suprachiasmatic nuclei inhibit corticosterone release. Brain Res 580:62-67.

Krémarik P, Freund-Mercier M-J, Stoeckel M-E (1992) Histoautoradiographic detection of oxytocin- and vasopressin-binding sites in the telencephalon of the rat. J Comp Neurol 333:343-359.

Krémarik P, Freund-Mercier MJ, Stoeckel ME (1995) Oestrogen-sensitive oxytocin binding sites are differentially regulated by progesterone in the telencephalon and the hypothalamus of the rat. J Neuroendocrinol 7:281-289.

Lang RE, Heil JW, Ganten D, Hermann K, Unger T, Rascher W (1983) Oxytocin unlike vasopressin is a stress hormone in the rat. Neuroendocrinology 37:314-316.

Liberzon I, Young EA (1997) Effects of stress and glucocorticoids on CNS oxytocin receptor binding. Psychoneuroendocrinology 22:411-422.

Lightman SL, Windle RJ, Wood SA, Kershaw YM, Shanks N, Ingram CD (2001) Peripartum plasticity within the hypothalamo-pituitary-adrenal axis. Prog Brain Res 133:111-129.

Ludwig M (1998) Dendritic release of vasopressin and oxytocin. J Neuroendocrinol 10:881-895

McCarthy MM, McDonald CH, Brooks PJ, Goldman D (1996) An anxiolytic action of oxytocin is enhanced by estrogen in the mouse. Physiol Behav 60:1209-1215

Melia KR, Ryabinin AE, Schroeder R, Bloom FE, Wilson MC (1994) Induction and habituation of immediate-early gene expression in rat brain by acute and repeated restraint stress. J Neurosci 14:5929-5938.

Mens WB, Witter A, van Wimersma Greidanus TB (1983) Penetration of 
neurohypophyseal hormones from plasma into cerebrospinal fluid (CSF): half-times of disappearance of these neuropeptides from CSF. Brain Res 262:143-149.

Mühlethaler M, Sawyer WH, Manning MM, Dreifuss JJ (1983) Characterization of a uterine-type oxytocin receptor in the rat hippocampus. Proc Natl Acad Sci USA 80:6713-6717.

Neumann I, Johnstone H, Hatzinger M, Liebsch G, Russell JA, Shipston MJ, Landgraf R, Douglas AJ (1998) Attenuated responses of the hypothalamo-pituitary-adrenal axis to stress in pregnant rats involve adenohypophysial changes. J Physiol (Lond) 1:289-300.

Neumann ID (2002) Involvement of the brain oxytocin system in stress: interactions with the hypothalamo-pituitary-adrenal axis. Prog Brain Res 139:147-162.

Neumann ID, Kromer SA, Toschi N, Ebner K (2000a) Brain oxytocin inhibits the (re)activity of the hypothalamo-pituitary-adrenal axis in male rats: involvement of hypothalamic and limbic brain regions. Regul Pept 96:31-38.

Neumann ID, Torner L, Wigger A (2000b) Brain oxytocin: differential inhibition of neuroendocrine stress responses and anxiety-related behaviour in virgin, pregnant and lactating rats. Neuroscience 95:567-575.

Neumann ID, Wigger A, Torner L, Holsboer F, Landgraf R (2000c) Brain oxytocin inhibits basal and stress-induced activity of the hypothalamopituitary-adrenal axis in male and female rats: partial action within the paraventricular nucleus. J Neuroendocrinol 12:235-243.

Nishioka T, Anselmo-Franci JA, Li P, Callahan MF, Morris M (1998) Stress increases oxytocin release within the hypothalamic paraventricular nucleus. Brain Res 781:57-61.

Patchev VK, Schlosser SF, Hassan AH, Almeida OFX (1993) Oxytocin binding sites in the rat limbic system and hypothalamic structures: site-specific modulation by adrenal and gonadal steroids. Neuroscience 57:537-543.

Paxinos G, Watson C (1998) The brain in stereotaxic coordinates, Ed 2. San Diego: Academic.

Petersson M, Hulting A-L, Uvnäs-Moberg K (1999) Oxytocin causes a sustained decrease in plasma corticosterone in rats. Neurosci Lett 264:41-44.

Richard Ph, Moos F, Freund-Mercier M-J (1991) Central effects of oxytocin. Physiol Rev 71:331-370.

Rivier C, Shen GH (1994) In the rat, endogenous nitric oxide modulates the response of the hypothalamic-pituitary-adrenal axis to interleukin-1 $\beta$, vasopressin, and oxytocin. J Neurosci 14:1985-1993.

Silverman AJ, Hoffman DL, Zimmerman EA (1981) The descending affer- ent connections of the paraventricular nucleus of the hypothalamus (PVN). Brain Res Bull 6:47-61.

Smith MA, Banerjee S, Gold PW, Glowa J (1992) Induction of $c$-fos mRNA in rat brain by conditioned and unconditioned stressors. Brain Res 578:135-141.

Tribollet E, Barberis C, Jard S, Dubois Dauphin M, Deifuss JJ (1988) Localization and pharmacological characterization of high affinity binding sites from vasopressin and oxytocin in the rat brain by light microscopic autoradiography. Brain Res 442:105-118.

Tsuchihashi T, Takata Y, Nakao Y, Tominaga M, Takishita S, Kobayas K, Abe I, Fujishima M (1993) Haemodynamic and humoral consequences of chronic infusion of vasopressin in conscious rats. Clin Exp Pharmacol Physiol 20:489-495.

Uvnäs-Moberg K, Ahlenius S, Hillegaart V, Alster P (1994) High doses of oxytocin cause sedation and low doses cause an anxiolytic-like effect in male rats. Pharmacol Biochem Behav 49:101-106.

Veinante P, Freund-Mercier MJ (1997) Distribution of oxytocin binding sites in the rat extended amygdala: a histoautoradiographic study. J Comp Neurol 383:305-325.

Wakerley JB, Terenzi MG, Housham SJ, Jiang QB, Ingram CD (1998) Electrophysiological effects of oxytocin within the bed nuclei of the stria terminalis: influence of reproductive stage and ovarian steroids. Prog Brain Res 119:317-330.

Walker DL, Toufexis DJ, Davis M (2003) Role of the bed nucleus of the stria terminalis versus the amygdala in fear, stress, and anxiety. Eur J Pharmacol 463:199-216.

Windle RJ, Shanks N, Lightman SL, Ingram CD (1997a) Central oxytocin administration reduces stress-induced corticosterone release and anxiety behavior in rats. Endocrinology 138:2829-2834.

Windle RJ, Wood S, Shanks N, Perks P, Conde GL, da Costa APC, Ingram CD, Lightman SL (1997b) Endocrine and behavioural responses top noise stress: comparison of virgins and lactating female rats during nondisrupted maternal activity. J Neuroendocrinol 9:407-414.

Wotjak CT, Ganster J, Kohl G, Holsboer F, Landgraf R, Engelmann M (1998) Dissociated central and peripheral release of vasopressin, but not oxytocin, in response to repeated swim stress: new insights into the secretory capacities of peptidergic neurons. Neuroscience 85:1209-1222.

Zaninetti M, Raggenbass M (2000) Oxytocin receptor agonists enhance inhibitory synaptic transmission in the rat hippocampus by activating interneurons in striatum pyramidale. Eur J Neurosci 12:3975-3984. 